\title{
VARIASI JENIS DAN METODE PEMBUATAN CETAKAN PASIR TERHADAP CACAT PENYINTERAN UNTUK PRODUK HOUSING DAN FRAME
}

\author{
Martin Doloksaribu (martin-d@kemenperin.go.id) \\ Sri Bimo Pratomo (sribimo@yahoo.com) \\ Balai Besar Logam dan Mesin, Kementerian Perindustrian \\ Jalan Sangkuriang Nomor 12 Bandung 40135
}

\begin{abstract}
ABSTRAK
Jenis dan metode pembuatan cetakan pasir dapat menimbulkan kemungkinan terjadinya cacat penyinteran. Cacat penyinteran sering muncul pada produk cor dengan dimensi yang relafif besar dan tebal. Produk Frame dan Housing memiliki dimensi dan ketabalan relatif tinggi terdapat cacat penyinteran pada pemukaannya. Pada penelitian ini cacat penyinteran pada permukaan produk tersebut dikurangi dengan menggunakan variasi jenis resin dan metode pembuatan cetakan pasir. Digunakan 2 jenis resin yaitu resin alpha dan resin water glass. Cetakan pasir dari resin alpha dibuat dengan 2 metode pencetakan yaitu cetakan pasir dibuat dari pasir reklamasi dari mesin Alkali Phenol Process (variasi 1) dan cetakan pasir dibuat dari kombinasi pasir baru sebagai facing sand dan pasir reklamasi dari mesin Alkali Phenol Process sebagai back sand (variasi 2). Cetakan pasir dari resin water glass dibuat hanya dengan 1 metode pencetakan (variasi 3). Pengujian kuat tekan, lost of ignition (LOI) dan distribusi pasir dilakukan terhadap 3 variasi tersebut. Kuat tekan akhir (saat pouring) dari 3 variasi tersebut adalah 11,90; 12,30 dan 18,70 (facing sand dan back sand); dan 12,02 $\mathrm{kgf} / \mathrm{cm}^{2}$. Nilai LOI adalah 1,$64 ; 0,82$ dan 1,73 ; dan $0,95 \%$. Ukuran distribusi pasir yang digunakan didominasi oleh ukuran saringan $0,5 \mathrm{~mm}(27 \%), 0,355 \mathrm{~mm}(10 \%)$ dan $0,250 \mathrm{~mm}(7,41 \%)$ atau AFS GFN sebesar 29. Cetakan pasir yang paling sedikit memberikan cacat penyinteran pada permukaan produk adalah cetakan pasir yang dibuat dengan resin alpha dengan metode pencetakan menggunakan kombinasi pasir baru sebagai facing sand dan pasir reklamasi sebagai back sand (variasi 2).
\end{abstract}

Kata Kunci: cacat penyinteran, resin alpha, resin water glass, kuat tekan, LOI, distribusi pasir

\begin{abstract}
Type and method of sand molds making can affect the possibility of sintering defect on surface of casting product. Sintering defect frequently appear on casting product with big and thick dimension. Surfcace of casting product of Frame and Housing show many sintering defect. The aim of this research is to reduced sintering defects by using types of resin and types of mold making method. Alpha resin and water glass resin are selected. Alpha resin sand mold is produced by 2 variation of sand mold making method. First variation is alpha resin sand mold with one layer. Second variation is alpha resin sand mold with two layers: back sand layer and facing sand layer. Third variation is water glass resin with $\mathrm{CO}_{2}$ method. Test of compressive strength, Lost of Ignition (LOI) and sand size distribution were carried out. Compressive strength value of 3 variations are 11.90; 12.30 and 18.70 (for facing sand and back sand); and $12.02 \mathrm{kgf} / \mathrm{cm}^{2}$. The value of LOI are 1.64; 0.82 and 1.73 (for facing sand and back sand); and 0.95\%. The sand size distribution is dominated by a $0.5 \mathrm{~mm}$ sieve size (27\%), $0.355 \mathrm{~mm}(10 \%)$ and $0.250 \mathrm{~mm}(7.41 \%)$ as AFS GFN is 29. Second variation sand mold gives the minimum sintering defect mark on surface.
\end{abstract}

Keywords: sintering defect, alpha resin, water glass resin, compressive strength, LOI, sand size distribution

\section{PENDAHULUAN}

Cacat penyinteran merupakan salah satu jenis cacat cor yang sering terjadi terutama pada produk cor yang berukuran besar. Produk cor yang memiliki ukuran yang relatif besar akan membutuhkan cairan logam yang besar. Hal tersebut akan membutuhkan pouring time yang lebih lama. Dengan kondisi tersebut, pasir cetak pada bagian permukaan dalam (bagian permukaan yang bersentuhan dengan logam cair) akan menerima panas lebih lama dan menerima tekanan dari logam cair yang lebih besar dibandingkan dengan cetakan produk yang relatif lebih kecil. Hal demikian dapat menyebabkan terjadinya hot spot pada daerah-daerah tertentu. Jika pasir cetak pada 
bagian permukaan dalam yang bersentuhan langsung dengan logam cair tidak memiliki kualitas yang baik maka pasir akan mudah terpenetrasi oleh cairan logam dan akan terjadi reaksi antara pasir dan cairan logam. Akibat penetrasi tersebut, butir pasir akan berikatan dengan cairan logam (penyinteran). Cacat penyinteran tampak sebagai permukaan yang kasar dan keras sehingga sulit untuk dibersihkan.

Cacat penyinteran disebabkan oleh beberapa faktor yang saling mempengaruhi. Faktor-faktor tersebut antara lain kualitas cetakan pasir, jenis pengikat cetakan pasir, bentuk dan dimensi produk cor dan juga temperatur cairan logam saat penuangan (pouring)(1). Oleh karena itu, untuk meminimalkan atau mengurangi terjadinya cacat penyinteran dibutuhkan pemahaman yang terintegrasi dari penyebab cacat ini. Pada penelitian ini cacat penyinteran akan dikurangi dengan variasi jenis resin dan metode pembuatan cetakan pasir. Kualitas pasir cetak akan diamati terhadap terjadinya cacat penyinteran.

Kegiatan penelitian ini merupakan kegiatan in-house research yang dikerjakan di Workshop Pengecoran dan Perlakuan Panas Balai Besar Logam dan Mesin dari bulan September s.d Desember 2014.

\section{Cacat Penyinteran}

Penyinteran adalah proses penempelan antar permukaan partikel (serbuk) solid karena adanya panas dan tekanan(2). Partikel solid tersebut ketika saling menempel belum mencapai fasa likuid. Temperatur saat partikel tersebut mencapai kondisi saling menempel di bagian permukaan dinamakan temperatur penyinteran (titik penyinteran). Temperatur penyinteran (sintering point) akan terjadi beberapa saat sebelum mencapai temperatur lebur (melting point).

Cacat penyinteran terjadi pada saat penuangan cairan logam. Pada saat proses penuangan cairan logam ke dalam cetakan, permukaan rongga cetakan (permukaan bagian dalam) akan mengalami gaya tekan dari logam cair akibat gravitasi. Selain gaya tekan akibat gravitasi, logam cair juga akan memberikan tekanan akibat panas cairan logam. Penyinteran yang terjadi pada saat penuangan cairan logam terjadi secara alami. Penyinteran yang terjadi pada proses pengecoran berbeda dengan penyinteran yang dilakukan pada proses manufaktur pada serbuk logam. Oleh karena itu penyinteran yang terjadi pada proses pengecoran tidak dapat sepenuhnya diprediksi. Gaya tekan akibat gravitasi dan panas yang diberikan oleh cairan logam menyebabkan terjadi penyatuan (penempelan) di antara butiran pasir dengan logam cair. Logam cair bersama dengan butiran pasir yang saling menempel akan tersolidifikasi sehingga membentuk permukaan yang kasar dan keras. Permukaan tersebut sangat keras sehingga sulit untuk dibersihkan. Jika hal tersebut terjadi pada permukaan benda cor maka produk cor tersebut tidak dapat digunakan atau dilanjutkan ke proses berikutnya.

\section{Karakteristik Pasir Cetak}

Salah satu cara untuk menghindari terjadi cacat penyinteran pada permukaan benda cor adalah dengan memperhatikan memperhatikan kualitas pasir cetak yang digunakan. Beberapa sifat sebagai berikut(2,3):

a. Ketahanan terhadap panas yaitu ketahanan pasir terhadap titik sinter. Pasir cetak harus memiliki titik sinter di atas temperatur tuang logam cair (pouring temperature). Jika pasir cetak memiliki titik sinter di bawah temperatur tuang logam cair maka akan terjadi penyinteran antara butir pasir dengan logam cair.

b. Kuat tekan yaitu kekuatan untuk menahan gaya tekan dari logam cair. Kualitas ini penting supaya permukaan dalam rongga cetakan tidak runtuh ketika dilalui oleh logam cair. Cairan logam akan memberikan tekanan akibat gaya gravitasi dan juga akibat panas dari cairan logam.

c. Distribusi/persebaran ukuran pasir yaitu variasi ukuran pasir dari pasir yang digunakan. Variasi ukuran pasir harus memadai agar dapat menutup rongga antar butir pasir.

d. Permeabilitas yaitu kemampuan pasir cetak untuk mengalirkan gas dari dalam cetakan ke luar cetakan. Hal ini sangat akan mempengaruhi pembebasan gas dari rongga cetak dan kecepatan pendinginan produk cor. Gas yang terperangkap di dalam cetakan dapat menyebabkan porositas. 


\section{Jenis Cetakan Pasir}

Terdapat beberapa cetakan pasir dalam proses pengecoran. Dalam penelitian ini menggunakan 2 jenis cetakan pasir yaitu jenis cetakan mengeras sendiri dan jenis cetakan yang mengeras akibat gas $\mathrm{CO}_{2}$. Jenis cetakan yang mengeras sendiri menggunakan bahan pengikat yaitu resin alpha. Pada jenis ini, pasir silika dicampur dengan hardener dan resin dengan komposisi yang sesuai sambil diaduk. Pasir dimampatkan ke dalam cetakan lalu cetakan pasir dibiarkan mengeras. Reaksi antara hardener dengan resin akan meningkatkan kekerasan cetakan pasir. Kekerasan akan terus meningkat sampai pada nilai tertentu. Pasir dari cetakan jenis ini dapat dipakai kembali untuk membuat cetakan pasir untuk produk lainnya.

Jenis cetakan pasir yang kedua adalah cetakan dengan proses $\mathrm{CO}_{2}$. Resin yang digunakan adalah resin water glass. Pasir dicampur dengan resin water glass dan diaduk lalu dimampatkan ke dalam cetakan. Kekerasan akan meningkat secara cepat akibat peniupan gas $\mathrm{CO}_{2}$ ke dalam cetakan. Gas $\mathrm{CO}_{2}$ ditiup ke dalam cetakan dengan menggunakan selang kecil. Pasir dari cetakan jenis ini tidak dapat digunakan kembali.

\section{Bentuk Butir Pasir}

Bentuk pasir digolongkan menjadi beberapa golongan yaitu bentuk butir pasir bundar, butir pasir sebagian bersudut, butir pasir bersudut dan butir pasir kristal $(2,4,5)$. Ilustrasi bentuk pasir dapat dilihat pada Gambar 1. Bentuk pasir akan mempengaruhi kekuatan dan permeabilitas dari cetakan pasir. Cetakan pasir yang baik terdiri dari ukuran dan bentuk butir pasir yang bervariasi.

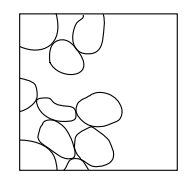

(a)

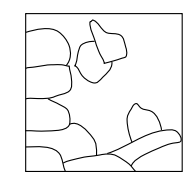

(b)

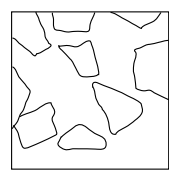

(c)

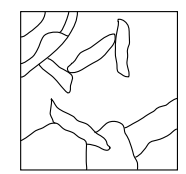

(d)
Gambar 1. Ilustrasi beberapa tipe bentuk butir pasir. (a) butir pasir bulat (b) butir pasir sebagian bersudut (c) butir pasir bersudut (d) butir pasir kristal

\section{Uji Pasir}

Kualitas pasir cetak ditentukan melalui pengujian terhadap sifat-sifat di atas. Dari hasil pengujian dapat disimpulkan kualitas dari pasir cetak. Pengujian pasir antara lain(5):

a. Kuat tekan. Pengujian ini dilakukan untuk mendapatkan nilai ketahan pasir terhadap gaya tekan yang diberikan. Nilai kuat tekan menunjukkan besar gaya tekan yang dapat diterima oleh pasir sebelum mengalami kerusakan.

b. Loss of Ignition (LOI). Pengujian ini dilakukan untuk mendapatkan nilai persentase berat yang hilang dari campuran pasir setelah dipanaskan. Nilai persentase menunjukkan berat yang hilang (menguap/terbakar) setelah diberikan panas selama durasi waktu tertentu.

c. Distribusi Pasir. Pengujian ini untuk mendapatkan persebaran ukuran pasir. Melalui pengujian ini didapatkan nilai (persentase) persebaran ukuran pasir. Pasir yang digunakan diharapkan memiliki persebaran ukuran pasir yang memadai.

\section{METODE PENELITIAN}

Dalam penelitian ini penanggulangan cacat penyinteran pada produk cor dilakukan dengan menggunakan beberapa jenis dan metode pembuatan cetakan pasir. Produk cor pada penelitian ini adalah Housing dan Frame. Berat produk masing-masing adalah sekitar $300 \mathrm{Kg}$ untuk Housing dan $200 \mathrm{Kg}$ untuk Frame. Berat tersebut sudah memperhitungkan berat sistem saluran tuang. Dimensi luar untuk Housing adalah 1115 x 600 x $240 \mathrm{~mm}$ (panjang $\mathrm{x}$ lebar $\mathrm{x}$ tinggi) dan untuk Frame adalah 933 × 574 x $161 \mathrm{~mm}$ (Gambar 2). Dimensi produk tersebut termasuk kategori besar sehingga pada saat pengecoran sangat mungkin terjadi hot spot (penumpukkan panas pada satu area) yang dapat menyebabkan terjadi penyinteran.

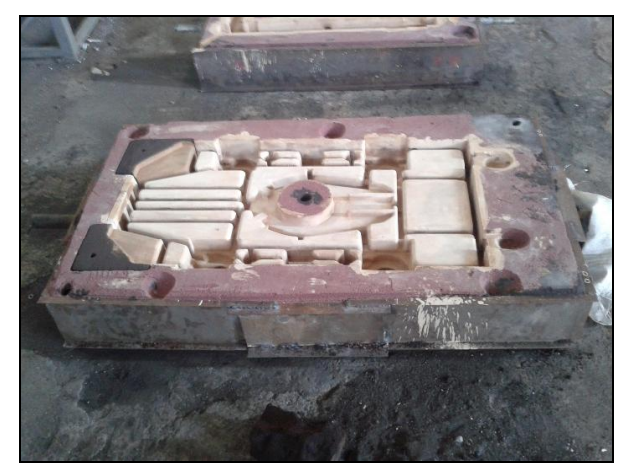

(a) 


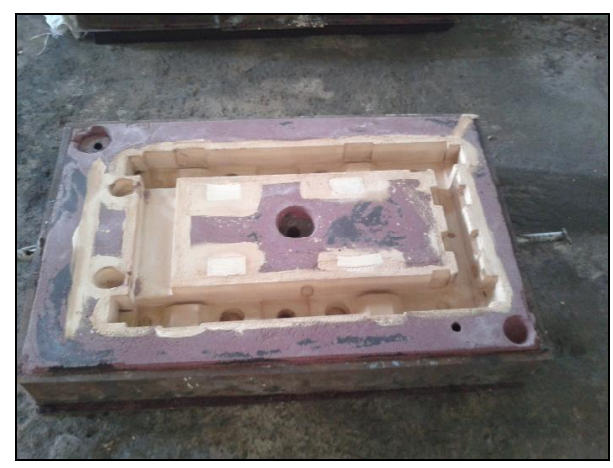

(b)

Gambar 2. (a) Cetakan pasir produk Housing dan (b) cetakan pasir produk Frame

Pada penelitian ini dibuat 3 variasi cetakan pasir (Gambar 3). Variasi 1 adalah cetakan dengan resin alpha. Cetakan pasir dibuat dengan menggunakan pasir dari pasir reklamasi. Pasir reklamasi didapat dari mesin dimana komposisi pencampuran pasir daur ulang, pasir baru, resin alpha dan hardener dilakukan oleh mesin (mesin Alkali Phenol Process). Pada mesin diatur agar komposisi berat pasir lama dan pasir baru adalah $70 \%$ pasir lama dan $30 \%$ pasir baru. Pengaturan keluaran resin adalah $26,50 \mathrm{~Hz}$ dan hardener adalah $35 \mathrm{~Hz}$. Pengaturan tersebut memberikan nilai persentase berat pencampuran resin yaitu $1,95 \%$ dari berat keluaran pasir dan persentase berat hardener yaitu 30,21\% dari berat berat keluaran resin. Resin alpha yang digunakan adalah Fenotec 820 dan hardener adalah Fenotec H20.

Cetakan variasi 2 adalah cetakan pasir yang dibuat dari kombinasi pasir dari mesin reklamasi dan pasir baru dimana pencampuran dilakukan secara manual menggunakan mixer. Pasir baru digunakan hanya untuk bagian facing sand untuk tetap menjaga faktor biaya pembuatan cetakan. Bahan resin dan hardener yang digunakan sama dengan bahan pada cetakan variasi 1. Pengaturan pada mesin reklamasi menggunakan pengaturan mesin untuk variasi 1. Pencampuran pasir baru (tanpa pasir daur ulang) dengan resin dan hardener digunakan sebagai facing sand yaitu pasir yang bersentuhan dengan permukaan pola. Berat resin adalah sekitar $2 \%$ dari berat pasir. Berat hardener adalah 25\% dari berat resin. Pasir reklamasi digunakan sebagai back sand yaitu lapisan pasir setelah facing sand.

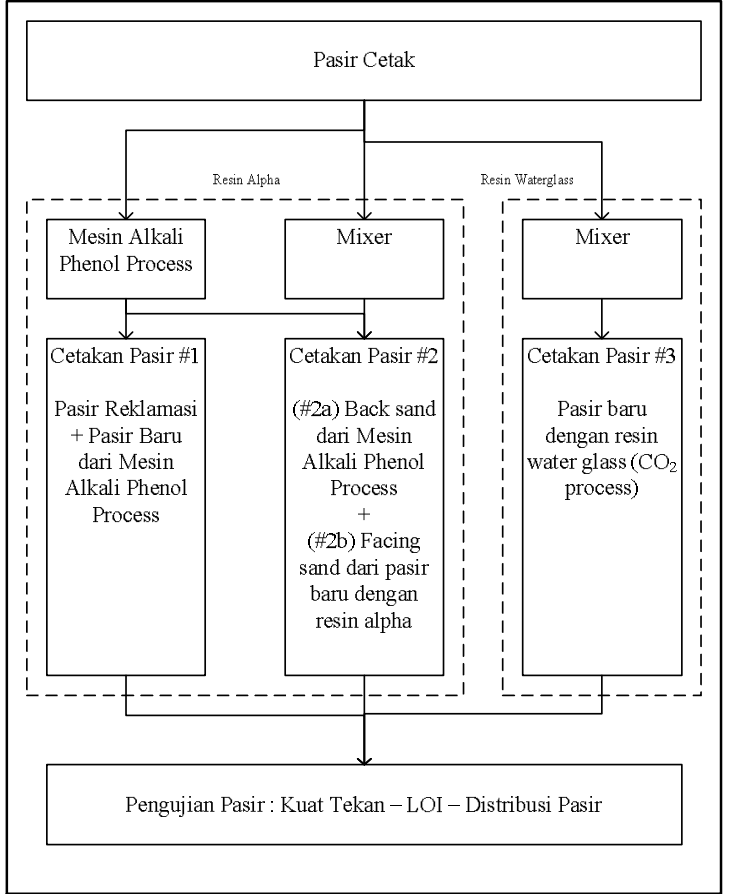

Gambar 3. Diagram alir penyiapan cetakan pasir

Cetakan variasi 3 adalah cetakan pasir dengan menggunakan resin water glass. Pasir dicampur dengan resin water glass. Pengerasan terjadi dengan meniupkan gas $\mathrm{CO}_{2}$ Pencampuran pasir dan resin water glass dilakukan dengan mixer. Berat resin water glass adalah 5\% dari berat pasir. Setelah pasir tercampur dengan resin, pasir dimasukkan ke rangka cetak dan dipadatkan. Setelah seluruh rangka cetak tertutup; gas $\mathrm{CO}_{2}$ ditiupkan ke dalam cetakan pasir menggunakan selang. selang. Gambar 3 adalah diagram alir pembuatan ke-3 variasi cetakan pasir.

Proses pengecoran dilakukan di Workshop Pengecoran. Perencanaan proses pengecoran dibuat oleh Urusan Keteknikan Seksi Pengecoran dan Perlakuan Panas. Proses pengecoran dilakukan pada temperatur tapping sekitar $1540^{\circ} \mathrm{C}$ dan temperatur tuang sekitar $1380^{\circ} \mathrm{C}$. Waktu tuang sekitar 20 detik untuk masing-masing produk. Komposisi target material adalah FCD 600.

\section{HASIL \& PEMBAHASAN Uji Kuat Tekan}

Nilai kuat tekan untuk 3 variasi cetakan pasir ditunjukkan pada Tabel 1. Pada jenis resin alpha, kekuatan tekan meningkat akibat adanya reaksi antara resin dan hardener. Kekuatan tekan akan meningkat terhadap lamanya reaksi antara resin dengan hardener. Proses pengerasan pada resin water glass berbeda dari resin alpha. Pada resin water- 
glass, proses pengerasan tidak dipengaruhi oleh lamanya waktu. Pengerasan akan meningkat secara signifikan pada saat gas $\mathrm{CO}_{2}$ ditiupkan ke dalam cetakan. Kekerasan tidak akan bertambah secara signifikan dengan semakin lamanya proses peniupan.

Tabel 1. Hasil uji kuat tekan untuk masing-masing variasi cetakan pasir untuk housing dan frame

\begin{tabular}{|c|c|c|c|c|}
\hline \multirow{3}{*}{$\begin{array}{c}\text { DURASI } \\
\text { (Jam) }\end{array}$} & \multicolumn{4}{|c|}{ KUAT TEKAN RATA-RATA $\left(\mathrm{kgf} / \mathrm{cm}^{2}\right)$} \\
\hline & \multirow[t]{2}{*}{1} & \multicolumn{2}{|c|}{2} & 3 \\
\hline & & $\begin{array}{l}2 \mathrm{a} \\
\text { BACK } \\
\text { SAND }\end{array}$ & $\begin{array}{c}2 \mathrm{~b} \\
\text { FACING } \\
\text { SAND }\end{array}$ & $\mathrm{CO}_{2}$ \\
\hline 0 & 0 & 0 & 0 & 0 \\
\hline 24 & $11.47 *$ & & & $12.02 *$ \\
\hline 99 & & 12.00 & 9.20 & \\
\hline 124 & & $18.70^{*}$ & $12.30 *$ & \\
\hline 145 & 11.50 & & & \\
\hline 170 & 11.90 & & & \\
\hline $\begin{array}{c}\text { Pengama } \\
\text { tan } \\
\text { visual } \\
\text { hasil cor } \\
\text { terhadap } \\
\text { cacat } \\
\text { penyinte } \\
\text { ran }\end{array}$ & $\begin{array}{l}\text { permukaan } \\
\text { relatif baik; } \\
\text { sedikit } \\
\text { cacat } \\
\text { penyinteran }\end{array}$ & \multicolumn{2}{|c|}{$\begin{array}{c}\text { Permukaan paling } \\
\text { baik dibandingkan } \\
\text { produk dari cetakan } \\
\text { \#1 dan \#3 }\end{array}$} & $\begin{array}{c}\text { Permukaan } \\
\text { banyak } \\
\text { terdapat } \\
\text { cacat } \\
\text { penyinteran }\end{array}$ \\
\hline
\end{tabular}

Nilai kuat tekan yang diperhatikan adalah nilai kuat tekan pada jam saat/mendekati cetakan dicor. Untuk variasi 1 dan 2, waktu akhir dimana cetakan dicor tidak sama. Cetakan variasi 1 dicor sekitar setelah 24 jam (sekitar 1 hari) setelah pencampuran atau mulai pembuatan cetakan. Untuk cetakan variasi 2 dicor setelah 124 jam (sekitar 5 hari). Untuk cetakan variasi 3 dicor setelah 24 jam (sekitar 1 hari) setelah pencampuran. Waktu pelaksanaan pengecoran berbeda-beda karena tergantung dari perencanaan yang dibuat oleh Seksi Pengecoran dan Perlakuan Panas.

Cetakan variasi 1 diuji tekan 24 jam setelah pencampuran. Waktu tersebut juga merupakan waktu cetakan dicor. Uji tekan pada jam ke-145 dan ke-170 tetap dilakukan untuk melihat peningkatan nilai kuat tekan. Dari pengujian didapatkan nilai kuat tekan $11,50 \mathrm{kgf} / \mathrm{cm}^{2}$ untuk jam ke-145 dan 11,90 $\mathrm{kgf} / \mathrm{cm}^{2}$ untuk jam ke-170. Dari nilai tersebut didapatkan bahwa nilai kuat tekan cetakan variasi 1 tidak mengalami peningkatan terhadap pertambahan waktu yang signifikan. Dari pengamatan visual permukaan produk dari cetakan variasi 1 didapatkan permukaan produk yang relatif baik.

Cetakan variasi 2 diuji pada jam ke-99 dan jam ke-124. Cetakan variasi 2 tidak diuji pada jam ke-24 karena diperkirakan nilai kuat tekan tidak berbeda jauh dengan cetakan variasi 1 karena menggunakan resin dan metode pembuatan cetakan yang sama. Namun pada pencampuran pasir untuk back sand, pada mesin reklamasi dilakukan beberapa perbaikan. Perbaikan tersebut menghasilkan pencampuran yang memberikan nilai kuat tekan yang lebih baik daripada cetakan variasi 1. Nilai kuat tekan facing sand diharapkan lebih tinggi dari pada back sand karena menggunakan pasir baru seluruhnya. Namun pada jam ke-124, back sand memiliki nilai yang lebih besar yaitu $18,70 \mathrm{kgf} / \mathrm{cm}^{2}$ sedangkan facing sand memiliki nilai kuat tekan sebesar 12,30 kgf/ $\mathrm{cm}^{2}$. Cetakan variasi 2 menghasilkan permukaan benda cor yang lebih baik daripada permukaan benda cor dengan cetakan variasi 1 . Oleh karena itu, cetakan pasir yang dibuat dari pasir baru dengan kuat tekan sekitar 11-12 $\mathrm{kgf} / \mathrm{cm}^{2}$ sudah mampu menghasilkan menahan peneterasi logam cair sehingga pada permukaan produk cor sedikit terdapat cacat penyinteran.

Dari grafik kuat tekan terhadap durasi waktu (Gambar 4) dapat dilihat bahwa nilai kuat tekan akhir dari cetakan 2 (untuk back sand dan facing sand) nilainya di atas dari cetakan variasi 1 . Nilai kuat tekan cetakan variasi 1 tidak mengalami peningkatan nilai kuat tekan dari jam ke-24 sampai dengan jam ke-170. Sedangkan cetakan variasi 2 mengalami peningkatan nilai kuat tekan yang signifikan dalam rentang jam ke-99 sampai dengan jam ke-124 khusunya pada cetakan pasir back sand. Nilai kuat tekan cetakan variasi 1 pada jam ke-124 sekitar 11,47 $11,50 \mathrm{kgf} / \mathrm{cm}^{2}$. Nilai ini sangat berdeda dibandingkan nilai kuat tekan cetakan variasi 2 untuk back sand. Namun nilai tersebut tidak berbeda jauh dengan cetakan variasi 2 facing sand. Walaupun cetakan variasi 1 dan cetakan varisi 2 untuk back sand diproses dengan mesin yang sama namun menghasilkan nilai kuat tekan yang berbeda. Proses pembuatan campuran pasir dengan mesin Alkali Phenol Process dipengaruhi oleh kondisi mesin tersebut khusunya pada bagian pencampuran.

Cetakan variasi 3 diuji pada jam ke-24 dan menghasilkan nilai kuat tekan sebesar $12,02 \mathrm{kgf} / \mathrm{cm}^{2}$. Cetakan pasir variasi 3 tidak diuji pada waktu yang lebih lama karena proses pengerasan tidak meningkat signifikan terhadap waktu. Nilai kuat tekan cetakan variasi 3 tidak berbeda jauh dengan cetakan variasi 1 dan facing sand cetakan variasi 2 . 
Namun dari pengamatan visual permukaan produk didapatkan banyak cacat penyinteran pada permukaan produk cor.

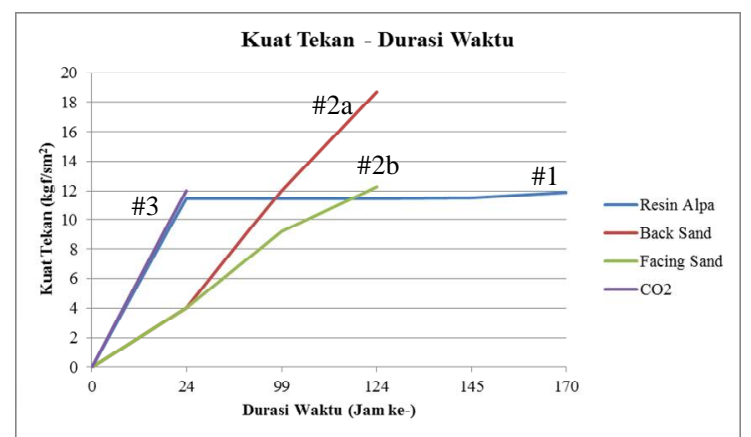

Gambar 4. Grafik nilai uji kuat tekan

Cetakan variasi 3 menghasilkan cacat penyinteran yang paling banyak (Gambar $5 b$ dan 5c) walaupun nilai kuat tekan pasir tidak berbeda jauh dengan cetakan variasi 1 dan cetakan variasi 2 bagian facing sand. Penyinteran terjadi hampir seluruh area bagian sisi dari produk Housing (Gambar 5b dan 5c). Pada produk Frame penyinteran terjadi di beberapa area namun relatif lebih sedikit daripada produk Housing.

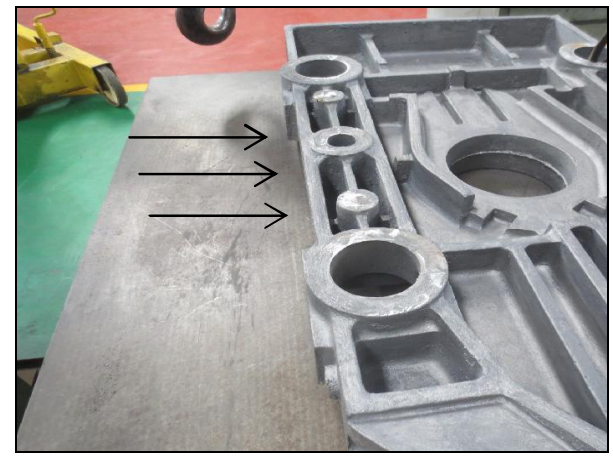

(a)

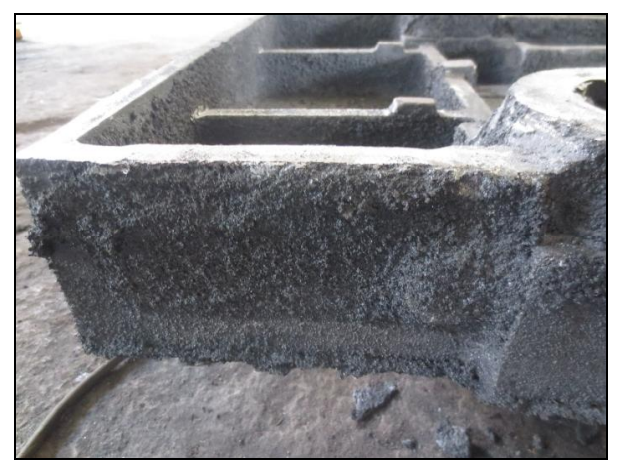

(b)

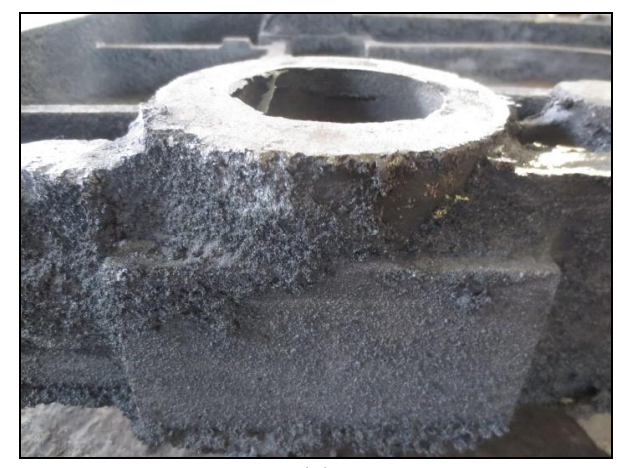

(c)

Gambar 5. Penyinteran pada produk Housing. (a) Produk Housing dari cetakan variasi 2 (tanda panah menunjukkan sisi terjadi cacat penyinteran). (b) dan

(c) Produk Housing dari cetakan variasi 3 dimana permukaan produk terdapat cacat penyiteran

\section{Uji LOI (Loss of Ignition)}

Hasil uji LOI dan grafik nilai uji LOI dari 3 variasi cetakan dapat dilihat pada Tabel 2 dan Gambar 6.

Tabel 2. Hasil uji LOI (rata-rata) tiap cetakan pasir

\begin{tabular}{|c|c|c|}
\hline $\begin{array}{c}\mathrm{N} \\
\mathrm{O}\end{array}$ & JENIS CETAKAN PASIR & $\begin{array}{c}\text { LOI } \\
(\%)\end{array}$ \\
\hline 1 & $\begin{array}{c}\text { Resin Apha-Mesin Alkali Phenol } \\
\text { Process }\end{array}$ & 1.64 \\
\hline 2a & $\begin{array}{c}\text { Resin Alpha-Mesin Alkali Phenol } \\
\text { Process - Back Sand }\end{array}$ & 1.73 \\
\hline 2b & Resin Alpha-Mixer - Facing Sand & 0.82 \\
\hline 3 & Resin Water Glass - $\mathrm{CO}_{2}$ & 0.95 \\
\hline
\end{tabular}

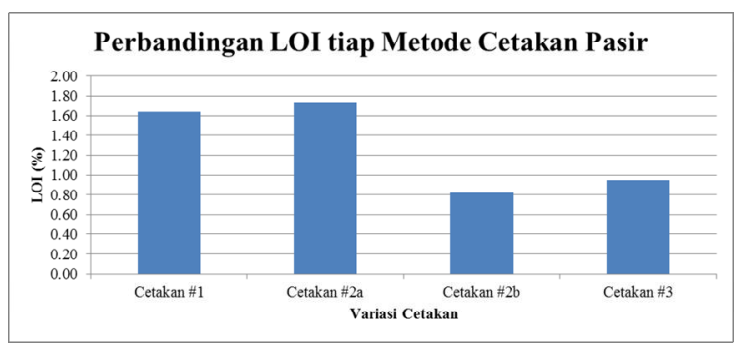

Gambar 6. Grafik nilai LOI (rata-rata) tiap cetakan

Nilai LOI cetakan variasi 1 dan cetakan variasi $2 \mathrm{a}$ tidak berbeda jauh yaitu 1,64 dan $1,73 \%$. Hal ini disebabkan oleh metode pembuatan cetakan pasir yang sama yaitu dengan mesin Alkali Phenol Process. Nilai LOI cetakan pasir resin alpha bagian facing sand (cetakan variasi $2 b$ ) memiliki nilai LOI yang paling rendah dibandingkan cetakan variasi lainnya (nilai LOI cetakan variasi 3 adalah $0,95 \%$ ). Nilai persentase LOI yang semakin rendah artinya semakin sedikit massa yang hilang setelah pemanasan. Nilai ini mengindikasikan persentase bagian pasir yang 
hilang akibat panas dari logam cair. Nilai LOI semakin kecil maka semakin sedikit bagian pasir yang hilang akibat panas dari logam cair. Cetakan variasi $2 \mathrm{~b}$ memiliki nilai LOI paling kecil sehingga cetakan variasi $2 \mathrm{~b}$ paling sedikit terpengaruh oleh panas dari logam cair. Hal ini dapat terlihat dari jumlah cacat penyinteran yang sedikit pada permukaan produk. Cetakan variasi 3 dengan nilai LOI di antara cetakan variasi 1 dan $2 \mathrm{~b}$ menghasilkan jumlah cacat penyinteran yang paling banyak. Hal tersebut disebabkan oleh ruang antar butir yang lebih besar. Ruang antar butir tersebut terjadi karena peniupan gas $\mathrm{CO}_{2}$ ke dalam cetakan. Proses peniupan tersebut menyebabkan ruang antar butir yang relatif lebih besar. Hal tersebut meningkatkan potensi terjadinya penetrasi logam cair ke dalam cetakan pasir sehingga banyak terjadi cacat penyinteran. Selain disebabkan oleh peniupan gas $\mathrm{CO} 2$, besarnya ruang antar butir dipengaruhi oleh distribusi dan bentuk butir pasir.

\section{Uji Distribusi Pasir dan Bentuk Butir Pasir}

Tabel 3 dan Gambar 7 menunjukkan hasil uji distribusi pasir yang digunakan pada penelitian ini. Tiap variasi cetakan menggunakan sumber pasir pasir baru yang sama. Untuk pasir lama (daur ulang) pada mesin Alkali Phonol Process menggunakan pasir lama yang tersedia pada mesin. Distribusi pasir baru didominasi oleh ukuran saringan $0,500 \mathrm{~mm}$ (sebanyak 27,22\%); $0,710 \mathrm{~mm}$ $(14,60 \%) ; 0,355 \mathrm{~mm}(10 \%) ; 0,180 \mathrm{~mm}$ $(7,41 \%)$ dan $0,180 \mathrm{~mm}(4,52 \%)($ AFS GFN $=$ 29). Dengan nilai distribusi pasir seperti ini, butir pasir masih mampu menutup ruang antar butir sehingga dapat mengurangi cacat penyinteran. Hal tersebut dapat dilihat dari permukaan produk yang relatif sedikit terjadi penyinteran untuk cetakan variasi 1 dan variasi 2.
Tabel 3. Hasil uji distribusi pasir

\begin{tabular}{|c|c|c|}
\hline NO & $\begin{array}{r}\text { UKURAN } \\
\text { SARINGAN }\end{array}$ & $\%$ berat \\
\hline 1 & 1.400 & 0.00 \\
\hline 2 & 1.000 & 0.81 \\
\hline 3 & 0.710 & 14.60 \\
\hline 4 & 0.500 & 27.22 \\
\hline 5 & 0.355 & 10.00 \\
\hline 6 & 0.250 & 7.41 \\
\hline 7 & 0.180 & 4.52 \\
\hline 8 & 0.125 & 0.46 \\
\hline 9 & 0.009 & 0.14 \\
\hline 10 & 0.063 & 0.00 \\
\hline 11 & Pan & 0.00 \\
\hline
\end{tabular}

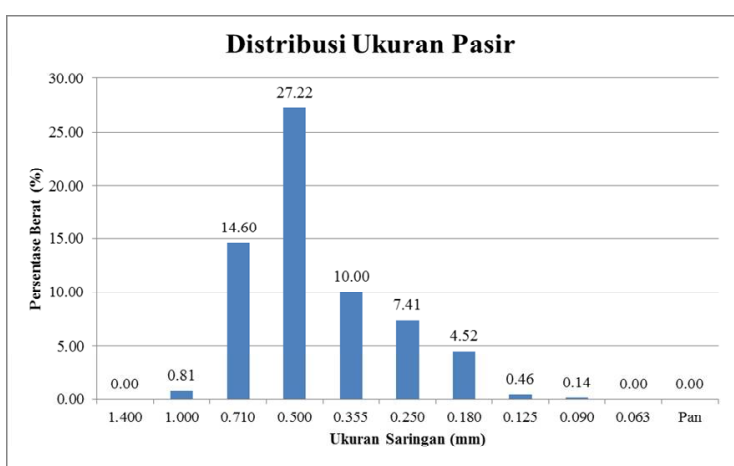

Gambar 7. Grafik distribusi ukuran pasir

Bentuk butir pasir diamati dengan mikroskop makro. Gambar 8 menunjukkan butir pasir yang digunakan pada penelitian ini. Bentuk pasir yang digunakan memiliki bentuk agak bersudut. Bentuk seperti itu akan menyebabkan ruang antar butir yang besar. Ruang antar butir yang besar menyebabkan peningkatan penetrasi logam cair ke dalam cetakan pasir. Bentuk butir agak bersudut ditambah dengan peniupan gas $\mathrm{CO}_{2}$ semakin memperbesar ruang antar butir sehingga pada jenis cetakan resin water glass - gas $\mathrm{CO}_{2}$ (cetakan variasi 3) menghasilkan jumlah cacat penyinteran yang paling banyak dibandingkan variasi lainnya.

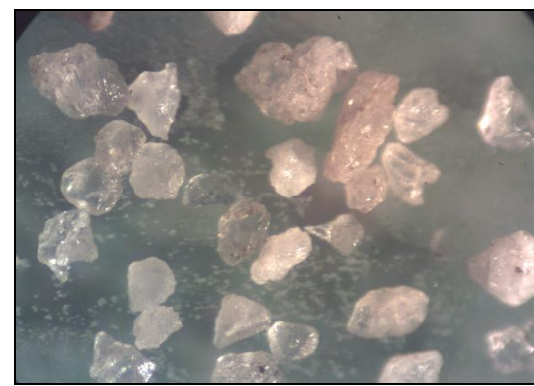

Gambar 8. Bentuk butir pasir; didominasi oleh bentuk butir pasir agak bersudut 


\section{KESIMPULAN \& SARAN}

Dari penelitian ini dapat diambil beberapa kesimpulan sebagai berikut:

1. Jenis dan metode cetakan pasir yang paling sedikit menghasilkan cacat penyinteran untuk produk Housing dan Frame adalah cetakan pasir resin alpha dengan penggunaan pasir baru sebagai facing sand (cetakan variasi 2).

2. Nilai kuat tekan yang semakin besar dan LOI yang semakin kecil memperkecil potensi terjadinya cacat penyinteran pada produk berukuran relatif besar., distribusi pasir dan bentuk pasir memberikan pengaruh terhadap terjadinya cacat penyinteran.

3. Distribusi ukuran pasir dan bentuk pasir memberikan pengaruh terhadap terjadinya cacat penyinteran.

4. Perlu dilakukan penelitian kualitas cetakan pasir resin alpha terhadap penyinteran dengan persentase resin dan hardener yang berbeda pada lokasi cacat penyinteran tertentu.

\section{DAFTAR PUSTAKA}

1. Beeley, P.R. 1972. Foundry Technology. London:Butterworths.

2. Surdia, Tata \& Chiijiwa, Kenji. 2013. Teknik Pengecoran Logam, cetakan 10. Jakarta: Balai Pustaka.

3. A. Sanders, Clyde. 1973. Foundry Sand Practice, Sixth Edition. Illiones:American Colloid Company.

4. ASM Handbook Volume 15 Casting. 1992. Amerika:ASM International The Materials Information Company.

5. AFS Mold and Core Test Handbook.American Society Foundryman.

6. Latief, A. Sutowo. 2012. Kajian tentang Suhu Sinter dan Suhu Lebur Pasir Merapi sebagai Potensi Sumber Daya Alam yang Mendukung Industri Pengecoran Logam di Jawa Tengah. Indonesia.

7. Brown, John, R. 2000. Foseco Ferrous Foundryman's Handbook. Oxford:Butterworth-Heinemann.

8. Purbowo, Tedy dan Tjitro, Soejono. 2003. Studi Penambahan Gula Tetes Pada Cetakan Pasir Terhadap Cacat Blow-hole, Jurusan Teknik Mesin, Fakultas Teknologi Industri, Universitas Kristen Petra, Jurnal Teknik Mesin Volume 5 Nomor 2. 